\title{
A Sediment Strategy For Coastal Zone Climate Change Adaptation
}

\author{
Job Dronkers, (job.dronkers@deltares.nl) and Jan Mulder (jan.mulder@deltars.nl) Deltares, \\ Netherlands
}

\begin{abstract}
There is no doubt that climate change will raise the sea level, even if there is quite some uncertainty about when and how much. Along all continental shores, beaches and wetlands will be drowned. One may also expect that extreme water levels will occur more frequently and that they will cause greater damage. Low-lying sedimentary coasts will be most affected. However, these coasts will not remain passive. Like during the Holocene marine transgression, natural sedimentary processes will produce changes in the coastal morphology. Morphodynamics will mitigate the negative impact of a higher sea level at some places, such that the bathymetry keeps pace with sea level. At other places however, morphodynamics will exacerbate the negative impact of sea-level rise by enhancing coastal retreat. The present experience with artificial coastal nourishment learns that we can take advantage of natural coastal morphodynamics to counteract this enhanced coastal retreat. A sediment strategy aims at mitigating the negative impact of sea-level rise by a set of measures that take optimal use of existing natural morphodynamic processes and existing sand or gravel resources. These measures and the underlying conditions are discussed in this paper.
\end{abstract}

\section{The active coastal zone}

Sedimentary coasts respond dynamically to the action of waves and currents. In shallow water, waves and current have the capacity to pick up sedimentary particles from the seafloor and to transport them across and along the shore. Areas where wave and current action are strongest generally erode, while areas where wave and current action are weakest accrete. These areas are variable according to temporal fluctuations in the strength of currents and waves. The active coastal zone is a coastal strip with alternating accretion and erosion by a permanent internal redistribution of sediment. It covers the following areas:

- The active foreshore, i.e. the underwater zone extending from the dry beach down to the greatest depth where wave and current action mobilize sedimentary particles. This limit corresponds to the so-called 'closure depth', which is the depth where uptake of sediment occurs so seldom that transport of this sediment across the closure depth contour does not contribute significantly to the sediment balance of the active coastal zone [Hallermeyer 1981]. The closure depth is typically between 5 and 15 meters for most coastal zones, but it is much greater for coasts directly impacted by ocean swell.

- The subareal zone, which includes the dry beach and the dune area up till the highest point that can be eroded under extreme storm conditions. 
- Inlets, estuaries and lagoons, where erosion and deposition of marine sediment alternate in response to wave and current action (including the possible influence of biotic processes).

Net offshore transport of coarse-grained sand and gravel occurs during storms. These sediments hardly cross the closure depth contour and return to the shore under average wave conditions. The active zone thus constitutes a dynamic buffer for temporal coastline fluctuations due to storms. At accreting coasts, aeolian processes often produce a net onshore transport of sand to the dune area beyond the active zone.

Sediments can also be transported longshore and get trapped in sediment sink zones, for instance in coastal lagoons. They often migrate via intermediate storage zones, for instance ebb tidal deltas and headland shoals. Sediments can also get "lost" from the active coastal zone into artificial deposition areas, such as harbours and navigation channels.

Lagoons that interact morphodynamically with coastal hydrodynamics, are considered part of the active coastal zone. This is in particular the case for tidal lagoons, where intertidal and subtidal areas follow the mean sea level, if sea-level rise is not too fast. When sea level rises, marshes accrete and rejuvenate their vegetation. This sedimentation may also reduce the turbidity in the lagoon. However, in the case of rapid sea-level rise and insufficient sediment availability, intertidal zones may become subtidal. A decrease of intertidal area alters tidal propagation, resulting in a relative increase of flood currents over ebb currents. Artificial sediment nourishment of the flood flow at the tidal inlet may then contribute to inland sediment transport and subsequent restoration of intertidal zones and marshes. The flood flow will likely nourish itself, however, by taking away sediment from the ebb tidal delta or from the adjacent coast. The beach and the foreshore then suffer an additional sediment loss.

Even without this additional sediment loss, natural onshore sediment transport on the open coast is generally insufficient for raising the active coastal zone in pace with sea level. The coast will therefore retreat.

\section{Coastal retreat}

Sea-level rise produces coastline retreat by drowning the beach. Coastal retreat due to sealevel rise does not exactly proceed in this way, however. In fact, the active zone responds to sea-level rise by vertical accretion and by an onshore shift, in such a way that the gross longterm average shape of the active coastal profile with respect to mean sea level is maintained. The resulting sediment demand is satisfied mainly by taking away sediment form the shore, causing coastal retreat.

In the absence of longshore transport gradients and in the absence of transport across the landward and seaward boundaries of the active coastal strip, the coastal retreat $\Delta /$ follows from the Bruun rule:

$$
\Delta / \approx \Delta h / \beta
$$


where $\Delta h$ is the rise of the mean sea level.

In the hypothetical case of a static beach, equation (1) would correspond to drowning of the beach and $\beta$ would be the beach slope at average water level. In reality, however, due to the dynamic response of the beach, the entire active coastal zone is shifted over a distance $\Delta l$. In this case $\beta$ is the average slope of the active coastal profile, including the active foreshore and the active beach and dune zone. This slope is generally smaller than the beach slope, i.e. typically of the order of $1 / 100$, while typical beach slopes are in the order of $1 / 20^{1}$. The dynamic response of the active coastal zone thus produces a stronger coastal retreat than simple drowning of a static beach. The reason is that vertical accretion of the lower part of the active coastal profile (to keep pace with sea level) creates a sediment demand that is satisfied by sediment input from the higher part of the active coastal zone.

Substitution in equation (1) of the typical value of $10^{-2}$ for $\beta$, shows that coastal retreat due to sea-level rise is about hundred times the amount by which the sea level rises. Application of this rule to European sedimentary coasts (sedimentary coastline length about 50.000 kilometers, sea-level rise about $2 \mathrm{~mm} / \mathrm{year}$ ) indicates a yearly net loss of coastal area of about $10 \mathrm{~km}^{2}$. A more accurate estimate based on actual measurements of coastline retreat along the European coastal zones yields a value of $15 \mathrm{~km}^{2}$. The larger observed value could eventually be explained by deposition of sediment in estuaries, coastal lagoons, headland sand banks, harbours, navigation channels and other deposition areas. Adaptation of the longshore coastal platform to a reduction of fluvial sediment supply and to the interruption of longshore transport by artificial structures (groins, breakwaters) also plays an important role. Beaches bounded by dikes or seawalls experience a faster retreat than natural sedimentary coasts, because there are no dunes that can deliver sediment for maintaining the active coastal equilibrium profile under sea-level rise.

Coastal retreat does not occur to the same extent along all European sedimentary coasts. Most of the observed coastal erosion takes place along particular coastal stretches which represent about $30 \%$ of the total sedimentary coastline. Therefore the Bruun rule has no great practical use for limited coastal stretches, even if it provides a useful order-ofmagnitude estimate of global coastal retreat due to sea-level change.

\section{Coastal nourishment}

There are nowadays several policy response options to coastal retreat. In the past, the only option was to accept coastal retreat and to abandon threatened settlements. This may still be a valid policy today, especially for coasts that are not strongly developed. For highly developed coasts, defending property is a more likely choice. In the past century, European coasts have been protected at many places with hard structures (many of which are now in a bad shape because of improper construction or poor maintenance). More recently, progress in our understanding of coastal morphodynamics has pointed to the crucial role of deficits in the sediment balance of the coastal zone. Simultaneously, development of dredging techniques has provided the means to repair eventual deficits in the coastal sediment

\footnotetext{
${ }^{1}$ For coarse grained coasts subject to strong wave activity ('reflective coasts') both values are higher, while for fine grained coasts with low wave activity the values are lower.
} 
balance. Consequently, a new concept has emerged for dealing with coastal retreat, the socalled sediment strategy.

The propensity of the active coastal zone to keep pace with sea level goes at the expense of beach and dune sand, with coastline retreat as a result. This coastal retreat can be avoided by nourishing the active zone such as to satisfy its sediment demand. Nourishment can take place on the beach, to compensate for the loss of beach sand to the submarine part of the active zone. It is also possible -and often less costly - to nourish directly the foreshore. Beach nourishment has the advantage of restoring directly the beach width. At longer term there is not much difference with foreshore nourishment, because sediment is redistributed over the active zone. Under sustained nourishment a new dune row is formed in front of the existing dune; the beach width will not grow indefinitely but remains limited.

Coastal nourishment owes much of its effectiveness to the fact that sand loss to deep water is small. Based on the assumption that offshore sand loss across the closure-depth contour is insignificant, it has been estimated that a yearly supply of about $6 \mathrm{Mm}^{3}$ (6 million $\mathrm{m}^{3}$ ) nourishment sand would be needed for maintaining all recreational beaches along the US coastline (coastline length approximately $3000 \mathrm{~km}$, sea-level rise about $2 \mathrm{~mm} / \mathrm{year}$ ). In this study a closure-depth contour has been assumed corresponding to the maximum depth where sand can be brought into suspension on average only once a year by extreme waves. Similar assumptions would imply that a yearly sand supply of about $100 \mathrm{Mm}^{3}$ is required for maintaining the entire sedimentary European coastline.

This estimate probably underrates substantially the real nourishment requirement, because other causes of sand loss and coastal retreat are disregarded. For the Dutch coast, with a sedimentary coastline of $350 \mathrm{~km}$, the required yearly artificial sand supply is estimated at 12 $\mathrm{Mm}^{3}$ at least, for a $2 \mathrm{~mm} /$ year sea-level rise. The US estimate for coastline maintenance per kilometer is about twenty times smaller than the estimate for the Dutch coast! Differences are mainly due to:

- A sand demand of about 7-8 $\mathrm{Mm}^{3}$, compensating for sand import to the Wadden Sea and other estuarine basins, which are morphologically active and tend to keep pace with sea level.

- A sand demand of about 1-2 $\mathrm{Mm}^{3}$, compensating for longshore sand redistribution along the Dutch coast due to cross-shore structures (lee erosion behind groins, harbour moles) and to other natural and man-induced departures from coastal equilibrium plane shape (e.g. closure dams).

- A sand loss to the dunes $\left(\approx 2 \mathrm{Mm}^{3}\right)$, behind the active zone.

- A sand loss across the closure depth contour considered by Leatherman; for the Dutch coast the active coastal strip is considered to extend till the $20 \mathrm{~m}$ depth contour.

The Netherlands has the most intensive coastal nourishment programme in Europe; it is also the country that borrows most sand from offshore. Besides the $12 \mathrm{Mm}^{3}$ for coastal nourishment, another $13 \mathrm{Mm}^{3}$ is extracted, mostly for raising the level of polder areas before building. Next comes the UK with about $14 \mathrm{Mm}^{3}$ of aggregate extraction, then Denmark with about $8 \mathrm{Mm}^{3}$ and France with about $6 \mathrm{Mm}^{3}$ [2007 figures, ICES 2008]. In these countries most of the borrowed sand and gravel is used in the construction industry. 


\section{Sediment sources for coastal nourishment}

Maintaining the coastal profile requires nourishment with the same type of sediment as present in the actual coastal profile. Coasts that are exposed to strong wave action are coarse grained, with the largest grains in the breaker zone and finer grains on the higher and lower parts of the active coastal strip. Sediment trapped in lagoons (including tidal lagoons) has on average a smaller grain size than the sediments deposited on the open coast. The crucial question for implementing a coastal nourishment strategy is: where can we find appropriate nourishment material?

Using land sources for coastal nourishment is expensive because of high winning and transportation costs; moreover, the environmental impact is often considerable. The use of marine sources - if situated not too far from the nourishment site - is more suitable.

The North Sea - and especially the Southern Bight - is a huge sand reservoir. It is estimated that during the Quaternary several hundred $\mathrm{km}^{3}$ of sand was deposited on the Dutch continental shelf. At least $17 \mathrm{~km}^{3}$ (maximum extraction depth below the sea floor of $5 \mathrm{~m}$ ) or $34 \mathrm{~km}^{3}$ (extraction depth $12 \mathrm{~m}$ ) can be extracted within 12 miles from the Dutch coast, taken into account not accessible areas due to cables, pipelines or nature areas. To a distance of $50 \mathrm{~km}$ from the coast another 40 resp. $80 \mathrm{~km}^{3}$ is available. Large quantities of sand and gravel are also present in the Channel and the Irish Sea.

In general, most sand deposits occur on broad continental shelves, especially where large river deltas existed in the past. Ancient consolidated sediments on such broad shelves may have been remobilised by abrasion due to wave and current action. Sand resources are much less abundant on tectonically active coasts with narrow continental shelf; during past geological cycles, most river sediment has slid downward the continental slope. This is for instance the case for rivers discharging to the southern European coast. The northern European shelf seas were also deprived from fluvial sediment most of the time during recent geological ages, because of glaciation. The large sand resources of the southern North Sea are rather an exception than a rule.

The strategic importance of sand resources, not only for coastal nourishment, but also for the construction industry, has triggered during the past decades seafloor survey programmes in European countries and in the US, see Fig. 1. Tracing offshore sand resources is not straightforward. Major sand resources on continental shelves correspond to drowned river deltas and relict coastlines. These deposits, which have (partially) resisted wave erosion during the Holocene marine transgression, have often been reworked into lenticular forms or rectilinear ridges. Relict sand deposits also occur in ancient channels carved into consolidated sediments. Offshore deposits are not necessarily located close to the present river mouth; the river mouth may have migrated in the course of time. Besides, longshore (wave-driven) currents may have transported sand bodies over large distances along the coastline ${ }^{2}$. Often a large proportion of the existing sand resources on the continental shelf is not economically or technically exploitable, because it is buried under layers of unsuitable material (mud, silt, lithified sediment,..), or because it is situated at too large depths. The

\footnotetext{
${ }^{2}$ For instance, the coasts of Israel and Libanon are nourished with sand from the Nile (Almagor G., Gill D. and Perath I., 2000. Marine sand resources offshore Israel. Marine georesources and geotechnology, 18, 1-42.)
} 
presence of submarine cables and pipelines may also limit the access to sand resources, for instance on the US Louisiana shelf.

Recent sand deposits on the shelf correspond to headland shoals and ebb tidal deltas. The latter deposits are generally thought to play a role in the morphodynamics of the tidal inlet system to which they are associated. Borrowing these deposits therefore entails the risk of destabilising the inlet system and related barrier islands. Borrowing sand from headland shoals is less risky, but these shoals contribute in some cases to protecting the coast from storm waves. In general, hydro- and morphodynamic studies are required to assess the risk of sand mining from near-shore resources.

On the French Atlantic shelf sand and gravel reservoirs total to several tenths of $\mathrm{km}^{3}$, but only a small part is exploitable. The exploitable sand reservoirs identified so far on the Mediterranean continental shelf of the southern European countries represent less than 1 $\mathrm{km}^{3}$, half of which are situated on the Catalonian shelf. In the 90ties an extensive seafloor survey programme has started for the US continental shelf. Offshore New York and New Jersey sand deposits of about $4 \mathrm{~km}^{3}$ have been found, associated with ancient capes and sand ridges. Sand resources on the Atlantic Florida shelf may even amount to almost 100 $\mathrm{km}^{3}$. In other continental shelf areas sand resources are more modest, for instance a few $\mathrm{km}^{3}$ in sand banks off the Texas and Louisiana coasts and in tidal ridges on the East Florida shelf. No quantitative figures exist for the Australian shelf, but geological investigations have revealed massive near-shore sand resources along most of the coastline, with the exception of the arid south-west coast.

Few investigations of sand resources exist on the shelves of other continents. Sand reservoirs of a few $\mathrm{km}^{3}$ have been reported for (parts of) the offshore coastal zones of Korea, China and New Zealand. But it is unlikely that a coastal nourishment strategy can provide a durable solution for all sedimentary coasts. For some coastal zones the offshore sediment reservoirs are sufficient for compensating coastal retreat when the sea level rises as much as a few meters. For other coastal zones only selected hotspots can be maintained in this way. There is a strong need to intensify the search for new offshore sand resources and to manage these resources carefully in order to preserve them for the most urgent nourishment needs.

\section{Sediment policy}

Sedimentary coasts are shaped by natural processes. These processes also operate to adapt the active coastal zone to sea-level rise. Coastal retreat can therefore be avoided by nourishing the active coastal zone at a rate approximately equal to surface active coastal zone multiplied by sea-level rise, if the characteristics of the supplied sediment match the existing sediment. This supply can be delivered by natural fluvial sources or by artificial nourishment. For realising a sediment strategy based on this principle it is crucial;

- To restore natural sediment flows, where they have been altered by river dams or by coastal breakwaters (for instance, by creating sediment bypasses or by removing obsolete structures). 


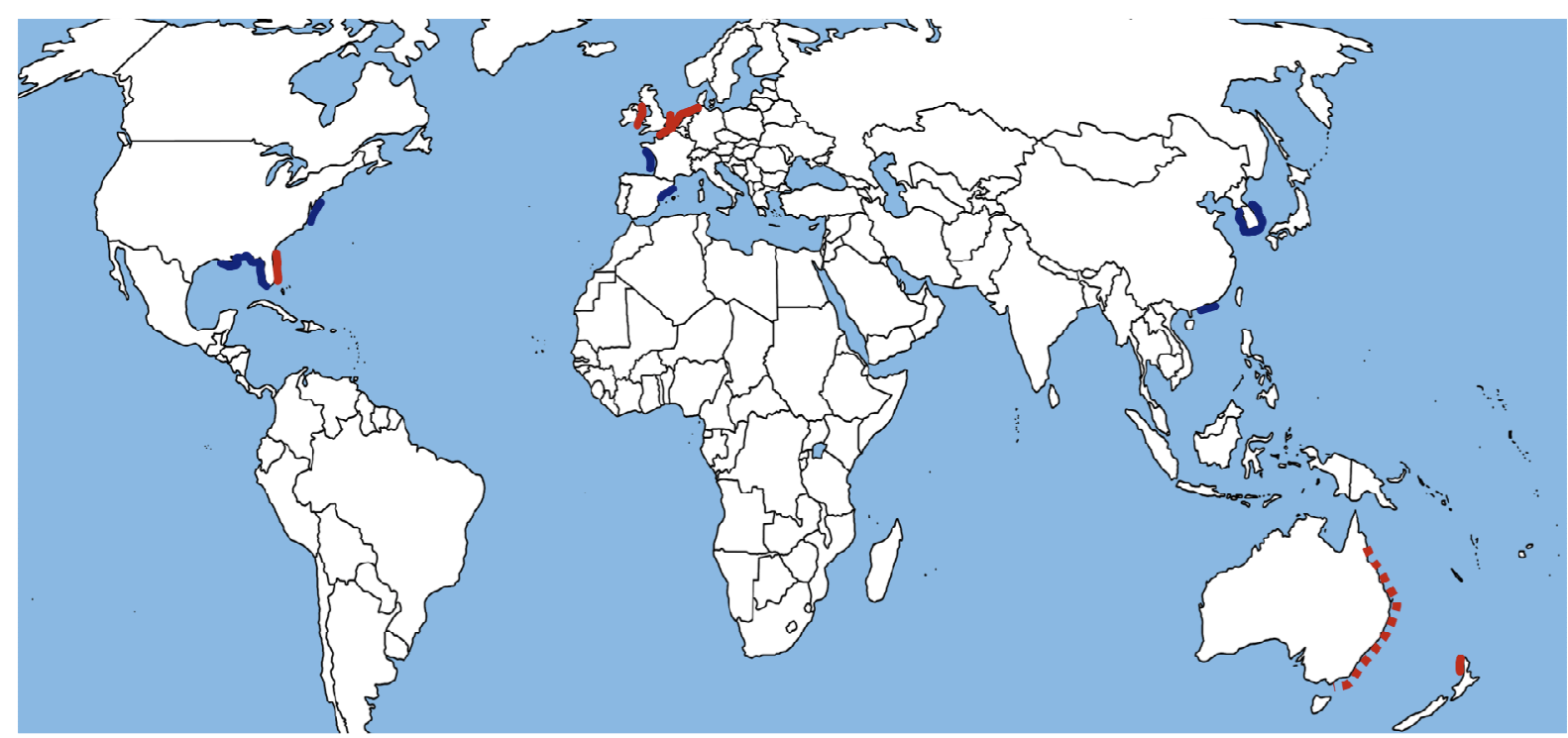

Fig. 1. Known nearshore sand resources. Dark-red: Exploitable resources larger than $1 \mathrm{~km}^{3}$ per $100 \mathrm{~km}$ sedimentary coastline, i.e. sufficient for compensating coastal retreat when the sea level rises several meters. Dark-blue: Exploitable resources larger than $0,1 \mathrm{~km}^{3}$ per $100 \mathrm{~km}$ coastline. Other coasts: resources smaller or unknown. Data from: Bliss J.D., Williams S.J., and Arsenault M.A., 2009. Mineral resource assessment of marine sand resources in cape- and ridge-associated deposits in three tracts, New York and New Jersey. In: Bliss, J.D. et al. Eds., Contributions to industrial-minerals research. US Geol. Survey Bull. 2209-N. http://pubs.usgs.gov/bul/b2209-n/ ; Finkl C.W., Andrews J.L. and Benedet, L., 2006. Assessment of offshore sand resources for beach nourishment along the southwest coast of Florida. http://www.fsbpa.com/2006\%20Proceedings.htm ; Finkl C.W., Andrews J.L., Suthard B.C.and Robertson, W., 2007. Geophysical and Geotechnical Determination of Sand Resources on the Florida Atlantic Continental Shelf: Preliminary Results. Procs. AGU Fall Meeting 2007 ; Finkl C.W., Benedet L., Andrews J.L., Suthard B. and Locker S.D., 2007. Sediment ridges on the west Florida inner continental shelf: sand resources for beach nourishment. J. of Coastal Res. 23, 143-159 ; Hume T., Green M., Nichol S. and Parnell, K., 2004. Kaipara sand study final report: Sand movement, storage and extraction in the Kaipara inlet. NIWA report. http://www.kaiparaharbour.net.nz/publications/ ; Ifremer 2008. Inventaire des ressources; matériaux marins. http://wwz.ifremer.fr/drogm/ressources minerales/materiaux marins/inventaire des ressources ; Kim J.Y., 2001. Quaternary geology and assessment of aggregate resources of Korea for the national industrial resources exploitation and development. Quaternary International, 82, 87-100 ; Morton R.A. and Gibeaut J.C., 1993. Physical and Environmental Assessment of Sand Resources - Texas Continental Shelf. Report prepared for the Minerala Management Servive of the US Department of the Interior. http://coastal.beg.utexas.edu/Coastal/pdf/Sand\%20Resources-Tx.Cont.\%20Shelf.pdf ; O'Mahony C., Sutton G., McMahon T., Ó'Cinnéide M. and Nixon E., 2008. Policy Report - Issues and Recommendations for the Development and Regulation of Marine Aggregate Extraction in the Irish Sea. Marine Environment \& Health Series, No. 32, 2008 ; Preti, M. et al., 2008. Recherche de Sable sous-marin en Mer Méditerranée. Beachmed projet Interreg IIIC, Extended report phase http://www.beachmed.it/Beachmede/SousProjets/RESAMME/tabid/91/Default.aspx ; Short A.D., 2010. Sediment Transport around Australia - Sources, Mechanisms, Rates and Barrier Forms. J. of Coastal Res. 26, 395-402 ; Zhang Q., Wang P., Wang W. and Zhang Y., 2010. Marine sand resources in the Pearl River estuary waters of China. J. of Marine Systems, in press. 
- To intensify the search for offshore sediment sources suitable for coastal nourishment. With present known sources only few coasts can be nourished durably to withstand future projected sea-level rise.

- To manage carefully existing offshore sand resources. If the resources are limited, their use should be prioritised and restricted to nourishment of coastal hot-spots. Marine spatial plans should be developed to guarantee the access to strategically important resources and to prevent pollution.

Other pertinent recommendations for the implementation of a sediment strategy (including consideration on the ecological impact of sand mining) can be found in the final reports of the EUROSION and CONSCIENCE projects.

\section{References}

Bruun P., 1954. Coast erosion and the development of beach profiles. Beach Erosion Board, US Army Corps of Engineers, Techn. Mem. 44, 1-79.

Dronkers J., 2005. Dynamics of Coastal Systems. World Scientific, 519 pp.

Eurosion 2004. Doody P. et al. eds. Living with Coastal Erosion in Europe. EC, Luxemburg. http://www.eurosion.org/reports-online/part1.pdf

Hallermeyer R.J., 1981. A profile zonation for seasonal sand beaches from wave climate. Coastal Engineering, 4, 253-277.

Hayes M.O., 1980. General morphology and sediment patterns in tidal inlets. Sedimentary Geology, 26, 139-156.

ICES 2008. Report of the Working Group on the Effect of Extraction of Marine Sediments on the Marine Ecosystem. http://www.ices.dk/reports/SSGHIE/2008/wgext08.pdf

Marchand, M. (ed.), 2010. Concepts for Science and Coastal Erosion Management. Deltares Delft. http://www.conscience-eu.net/documents/concise-report-final.pdf

Khalil, S.M. and FinkI C.W., 2009. Regional Sediment Management Strategies for Coastal Restoration in Louisiana, USA. J. of Coastal Res. SI 56, 1320-1324.

Komar P.D., 1998. Beach Processes and Sedimentation. Prentice-Hall, 544 pp.

Leatherman, S.P., 1989. National Assessment of Beach Nourishment Requirements Associated with Sea-Level Rise. US EPA Office of Policy, Planning and Evaluation. http://papers.risingsea.net/federal reports/rtc leatherman nourishment.pdf

Stolk A. 2010. Personal communication. 